\title{
Platelet Metabolism and Other Targeted Drugs; Potential Impact on Immunotherapy
}

\author{
Preeti Kanikarla-Marie, Michael Lam, Alexey V. Sorokin, Michael J. Overman, \\ Scott Kopetz and David G. Menter*
}

Department of GI Medical Oncology, The University of Texas MD Anderson Cancer Center, Houston, TX, United States

The role of platelets in cancer progression has been well recognized in the field of cancer biology. Emerging studies are elaborating further the additional roles and added extent that platelets play in promoting tumorigenesis. Platelets release factors that support tumor growth and also form heterotypic aggregates with tumor cells, which can provide an immune-evasive advantage. Their most critical role may be the inhibition of immune cell function that can negatively impact the body's ability in preventing tumor establishment and growth. This review summarizes the importance of platelets in tumor progression, therapeutic response, survival, and finally the notion of immunotherapy modulation being likely to benefit from the inclusion of platelet inhibitors.

OPEN ACCESS

Edited by:

Keiji Tanese,

Keio University, Japan

Reviewed by: Anca Maria Cimpean,

University of Medicine and Pharmacy,

Timisoara, Romania

Pin Wu,

Zhejiang University, China

*Correspondence:

David G. Menter

dmenter@mdanderson.org

Specialty section:

This article was submitted to Cancer Immunity and Immunotherapy,

a section of the journal

Frontiers in Oncology

Received: 07 January 2018 Accepted: 27 March 2018

Published: 20 April 2018

Citation:

Kanikarla-Marie $P$, Lam M

Sorokin AV, Overman MJ, Kopetz S and Menter DG (2018) Platelet

Metabolism and Other Targeted

Drugs; Potential Impact on Immunotherapy.

Front. Oncol. 8:107.

doi: 10.3389/fonc.2018.00107
Keywords: platelets, cyclooxygenase, platelet inhibitors, non-steroidal anti-inflammatory drugs, aspirin, immunotherapy

\section{INTRODUCTION}

Platelets arise from immune stem cell lineages in the bone marrow that are critically important in blood clotting and wound healing $(1,2)$. They are generated as cell fragments formed by membrane bound blebs at the surface of megakaryocytes. Platelets actively participate in the hemostasis, wounding, and immune processes required for normal functioning of the body $(1,2)$. In instances where the homeostasis is deregulated or dysfunctional, platelet functions can become aberrant. At times, even the thrombi formed for the resolution of the wounds may cause thromboembolic complications (3). Cancer is one such disease that can disrupt the normal functioning and production of platelets which in part is contributed by the pro-carcinogenic inflammatory milieu. There has been a long-standing link between cancers, thromboembolism, and thrombocytosis (4-6). Abnormalities in the number of platelets are most commonly observed in several cancers: colorectal, ovarian, and breast being some of them. Colorectal cancer (CRC) is one such type that is frequently associated with thrombocytosis with significant correlations for worse overall survival and recurrence rates (5, $7,8)$. High platelet counts in these patients also correlated with tumor invasiveness, metastasis, and worse survival outcomes (9-13).

It appears that platelets not only increase in numbers and get activated with cancer progression but also return to their normal levels and functional state following cancer therapy. These features of platelets can be tested in a relatively inexpensive and non-invasive manner using routine blood profiles and may serve as prognostic and diagnostic biomarkers of cancer. As a patient's disease progresses through the advanced stages of CRC, they can exhibit an increase in platelet activation with increased platelet factors and surface markers of activation (14-18). There are also reports showing that anticancer therapy could induce changes in the activation of platelets, their function, as well as their morphology (19). In the case of ovarian cancer, platelets were shown to increase the growth of cancer cells in vitro and in vivo animal models of cancer. Platelet alterations and thrombogenesis were seen in ovarian cancer patients (20-25). Mechanistically, IL6 production by an ovarian 
tumor can stimulate thrombopoietin production in the liver that elevates platelet production in the bone marrow (24). Platelets from ovarian cancer patients may also carry pro-coagulatory signatures based on their lipid profiles (26). The role of platelets in reducing cell death and enabling metastasis was also shown by activating YAP1 signaling in ovarian cancer (27). Similarly, many other reports show an active involvement of platelets in tumorigenesis and metastasis (28-32).

\section{PLATELET ACTIVATION AND PLATELET COUNTS IN CANCER}

Reactive platelets can recruit more platelets to form platelet aggregates and can also engage in heterotypic aggregates with leukocytes (33). Platelets upon activation release granules and extracellular vesicles that are rich in proteins, mRNA, miRNA, and lipids. These loaded particles can be involved in the transfer of receptors to the surface of other cells, including but not limited to lymphocytes, macrophages, and tumor cells by membrane fusions, and can also induce gene expression changes in the target cells by activating transcription factors (34-37). The transfer of cargo is not always unidirectional, as platelets that are in the vicinity of the tumor site can also take up RNA and other molecules from the tumor. The platelets that have undergone modifications after interacting with the tumor are termed as tumor-educated platelets (TEP). Recently, these TEPs have been explored for their significance and in extracting tumor-specific information (38). The reliability of using platelets to detect normal vs. tumoreducated platelet, along with the possible prediction of primary tumor location, all based on the platelet gene expression profiles has been successfully shown (39-42). The apparent benefits of such analyses involving platelet isolation could be diverse. The key feature of such tests is the ease of platelet isolation. Non-invasive blood-based liquid biopsies could be advantageous in early detection and screening of cancer. The importance of increased mean platelet volume, platelet counts, size, and platelet to lymphocyte ratio indexes in individuals has already been well recognized in predicting poor outcomes as well as in predicting association in diabetes, cerebral, and cardiovascular events (43-48). The same indices also may be predictive regarding cancer prognosis, treatment response outcomes, and overall survival analysis (49-55). An elevated platelet distribution width-to-platelet count ratio was shown to significantly reduce disease free survival in patients with breast carcinoma (52). As blood draw procedures are already in place and routinely used in cancer studies in a prospective or a retrospective fashion, the added benefit of achieving plateletrelated tumor-specific signature as described by Best et al., and the treatment outcomes could become a standard for cancer screening and diagnosis $(38-40,56)$.

\section{PLATELETS, SERUM GROWTH FACTORS, AND PLATELET-RICH PLASMA THERAPY}

Normal platelets in circulation range in number between 150,000 and $400,000 / \mu \mathrm{l}$. Based on sheer numbers and biologic properties there are many opportunities to engage in multiple aspects of tumor formation. In particular, it has long been known that platelets provide the bulk of the serum factors that promote cell growth, which is routinely used in culturing cells $(1,57-59)$. Platelet release reactions factors not only provide growth factors but also metalloproteinases involved in tissue reorganization (60-62) and have found clinical use in platelet-rich plasma therapy (60, 63-66).

\section{PLATELETS AND CIRCULATING TUMOR CELLS (CTCs)}

Once within the blood stream, tumor cells that enter the circulation are known as CTCs. These cells can become clinically evident when an established tumor starts to shed off cells from its bulk, or by other means such as sloughing, or even by active entry (intravasation) of cancer cells into abnormal tumor blood vessels (67-71). These are immediately sensed by the large number of platelets in the circulation and perivascular microenvironment (72-76). The cross talk between platelets and tumor cells leads to the rewiring of platelets as they become tumor-educated platelets. This interaction can result in the formation of heterotypic aggregates along with the release of growth promoting factors and the entrapment of the tumor cells with platelet aggregates in the microvasculature $(1,2)$. Platelets also have an active cytoskeleton enabling their unrestricted movements (77-79). In addition, properties such as the lack of a nucleus, discoid shape, and small size are ideal for platelets to migrate into extravascular tissues easily supporting the invasion of CTCs and their metastasis (1, $24,80-84)$. There is also evidence of platelets shielding the CTCs and protecting them from immune surveillance and elimination (85). The selective survival advantages that tumor cells gain from interacting with platelets enables them to withstand or evade immune attacks, take advantage of enhanced access to platelet released-growth factors. These interactions also benefit from relatively easy passage of platelets that invade unencumbered by a cell nucleus as they migrate into surrounding tissues due to their small size and active cytoskeleton. Then once in the perivascular spaces, factors released by platelets stimulates tumor cells to home, extravasate, and metastasize. Accordingly, a high probability exists that targeting or suppressing these tumor cell and platelet interactions would yield beneficial results. As one might expect, inhibiting this interaction of tumor cells with platelets was shown to hinder tumor cell survival, growth, and metastasis in experimental cancer models and had significance in clinical trials (86-94).

\section{TYROSINE KINASE INHIBITORS AND THE PLATELET CONNECTION}

The release of alpha granules leads to local increases in multiple growth factors and tyrosine kinase receptor activating molecules. Among the growth stimulating and vascular permeability regulating molecules like platelet-derived growth factor (PDGF) that are inhibited by a number of tyrosine kinase receptor inhibitors and may be influenced by targeted therapy $[(95,96)$; Table 1$]$. 
TABLE 1 | Platelet targeted therapeutics.

\begin{tabular}{|c|c|c|c|}
\hline Panel & Inhibitor type & Inhibitor & Target pathway \\
\hline \multirow[t]{3}{*}{ A } & vonWillebrand GPla/lla & Hookworm secretion & Surface receptor \\
\hline & Collagen GPVI & Revacept & Surface receptor \\
\hline & Focal adhesion kinase & $\begin{array}{l}\text { GSK2256098, PF-562271, Defactinib, PF-573228, Y15 } \\
\text { and Y11, CEP37440 }\end{array}$ & Kinase pathway \\
\hline \multirow[t]{2}{*}{$B$} & GPIlb/IIla & Abciximab, eptifibatide, tirofiban, XV454, heparins & Surface receptor \\
\hline & Vitronectin $\alpha \mathrm{V} / \beta 3$ & SB-273005, SC-68448, vitaxin & Surface receptor \\
\hline \multirow[t]{5}{*}{ C } & P-Selectin & Rivipansel, crizanlizumab, heparins & Surface receptor \\
\hline & CLEC-2 & 2CP, Mabs & Surface receptor \\
\hline & ROCK & Y27632 & Signal transduction \\
\hline & Myosin II & Blebbistatin & Signal transduction \\
\hline & PAR 1 and PAR 4 & Voraxopar, SCH 79797, RWJ56110 & $\mathrm{G}_{\mathrm{q}}$-protein-coupled receptor \\
\hline \multirow[t]{3}{*}{ D } & PDGFR & $\begin{array}{l}\text { Imatinib, sorafenib, sunitinib, nilotinib, dasatinib, axitinib, } \\
\text { cediranib, regorafinib, pazopanib, midosotaurin }\end{array}$ & Tyrosine kinase receptor pathway \\
\hline & VEGFR & $\begin{array}{l}\text { Bevecizimab, aflibercept, ramucirumab, sunitinib, lenvatinib, } \\
\text { vandetanib, sorafinib, pazopanib HCL, axaitinib, regroafinib, } \\
\text { cabozantinib }\end{array}$ & Tyrosine kinase receptor pathway \\
\hline & FcgammaRIla & Ranibizumab or bevacizuma & Tyrosine kinase receptor pathway \\
\hline \multirow[t]{2}{*}{$E$} & ADP receptor, $\mathrm{P}^{2} \mathrm{Y}_{1}$ & A2P5P, MRS2179, A3P5P, MRS2500 & $\mathrm{G}_{\alpha q}$-protein-coupled receptor \\
\hline & ADP receptor, $\mathrm{P}_{2} \mathrm{Y}_{12}$ & $\begin{array}{l}\text { Clopidogrel, ticlopidine, prasugrel, ticagrelor, cangrelor, } \\
\text { elinogrel }\end{array}$ & Gi-protein-coupled Receptor \\
\hline $\mathrm{F}$ & Serotonin receptor $5 \mathrm{HT}_{2 \mathrm{~A}} \mathrm{R}$ & ADP-791, naftidrofuryl, sarpogrelate, AT-1015 & $\mathrm{G}_{\alpha q}$-protein-coupled receptor \\
\hline \multirow[t]{3}{*}{ G } & Thromboxane $\mathrm{A}_{2}\left(\mathrm{TxA}_{2}\right)$ receptor $\alpha$ or $\beta$ & $\begin{array}{l}\text { Terutroban, daltroban, picotamide, sulotroban, CAY10535, } \\
\text { ifetroban, } S Q 29,548, B M 567 \text {, pinane } \operatorname{TxA}_{2}\end{array}$ & $\mathrm{G}_{12 / 13}$-protein-coupled receptor \\
\hline & Thromboxane $A_{2}$ Synthase & OKY-046, ridogrel & $\mathrm{TxA}_{2}$ synthesis enzyme \\
\hline & Cyclooxygenase 1 (COX-1) & $\begin{array}{l}\text { Aspirin, ASP6537, SC560, FR122047, mofezolac, } \\
\text { fluorofuranones }\end{array}$ & $\begin{array}{l}\text { Prostaglandin } \mathrm{H}_{2} \text { synthesis } \\
\text { enzyme (substrate for all PG } \\
\text { synthesis) }\end{array}$ \\
\hline \multirow[t]{2}{*}{$\mathrm{H}$} & Prostaglandin $\mathrm{E}_{2}\left(\mathrm{PGE}_{2}\right)$ receptor EP3 & DG-041 & $\mathrm{G}_{\alpha q}$-protein-coupled receptor \\
\hline & $\begin{array}{l}\text { 12-Hydroxyeicosa tetraenoic acid (12-HETE) } \\
\text { Receptor, GPR31 }\end{array}$ & ML355, NCTT-956 & G-protein-coupled receptor \\
\hline \multirow[t]{2}{*}{ I } & Prostacyclin $\left(\mathrm{PGI}_{2}\right)$ receptor & $\begin{array}{l}\mathrm{PGI}_{2} \text { agonist endogenous platelet inhibitor, iloprost, } \\
\text { treprostinil, selexipag }\end{array}$ & $\mathrm{G}_{\alpha \mathrm{s}}$-protein-coupled receptor \\
\hline & Phosphodiesterase (PDE) PDE3 and PDE5 & Cilostazol, dipyridamole, sildenafil & $\begin{array}{l}\text { Phosphodiesterase enzyme } \\
\text { inhibitor }\end{array}$ \\
\hline
\end{tabular}

This table summarizes the platelet-related targets, inhibitors, and pathway targets dipicted in Figure 1.

Likewise, vascular endothelial growth factor (VEGF) receptors and their inhibitors can be influenced by inhibitors that involve platelet alpha granule releasates (97-99). These factors affect endothelial cells, pericytes, lymphocytes, and tumor cells. They influence vascular permeability, angiogenesis, inflammation, and immune responsiveness. In addition to use in chemotherapy (95-99), there is renewed interest in these PDGFR and VEGFR targeted compounds in combination with checkpoint blockade inhibitors (100). Similarly, other immunoreceptor-based therapies can have a direct effect on FcgammaRIIa tyrosine kinase receptors in platelets. For example, BCR-ABL inhibitor ponatinib inhibits platelet immunoreceptor tyrosine-based activation motif (ITAM) signaling under shear which includes platelet activation and aggregate formation $(101,102)$. Overall, TKIs could potentially be reconsidered in the context of platelet function during immunotherapy.

\section{PLATELET METABOLISM TARGETED NON-STEROIDAL ANTI-INFLAMMATORY DRUG (NSAID) USE IN CANCER}

Given the importance of platelets in almost all aspects and stages of cancer progression, Table 1 highlights platelet inhibition pathways. The inhibition of platelets is receiving renewed attention as a target. Interest in inhibiting platelets heightens in the case of cancers where the disease risk increases with chronic inflammation. There have been a number of clinical trials addressing the role of platelets in cancer patients. The most commonly used drugs to target platelets are the NSAIDs. NSAIDs such as aspirin, rofecoxib, sulindac, and celecoxib are effective in reducing cancer but have potential cardiovascular risks (103-106). One of the most heavily used drug on the market is aspirin, it irreversibly acetylates platelet cyclooxygenase 1 
(COX-1), which is the rate limiting NSAID eicosanoid metabolic target found in platelets (Figure 1). By contrast, aspirin less selectively inhibits cyclooxygenase 2 (COX-2), expression, which is commonly upregulated in cancer (107). Despite gastrointestinal side effects that may be heightened in patients with preexisting gastric lesions, aspirin has been used in prevention studies as well as in experimental models of cancer to inhibit cancer cell growth, platelet-tumor cell interactions, heterotypic aggregate formation, platelet facilitated tumor cell invasion, and metastasis (108-113). In general, the risk/benefit of using aspirin is favorable over a given lifetime (114). Moreover, aspirin has also been used in combination therapies. In one study, breast cancer patients were given aspirin along with tamoxifen therapy, while in another study they were given aspirin along with clopidogrel in an effort
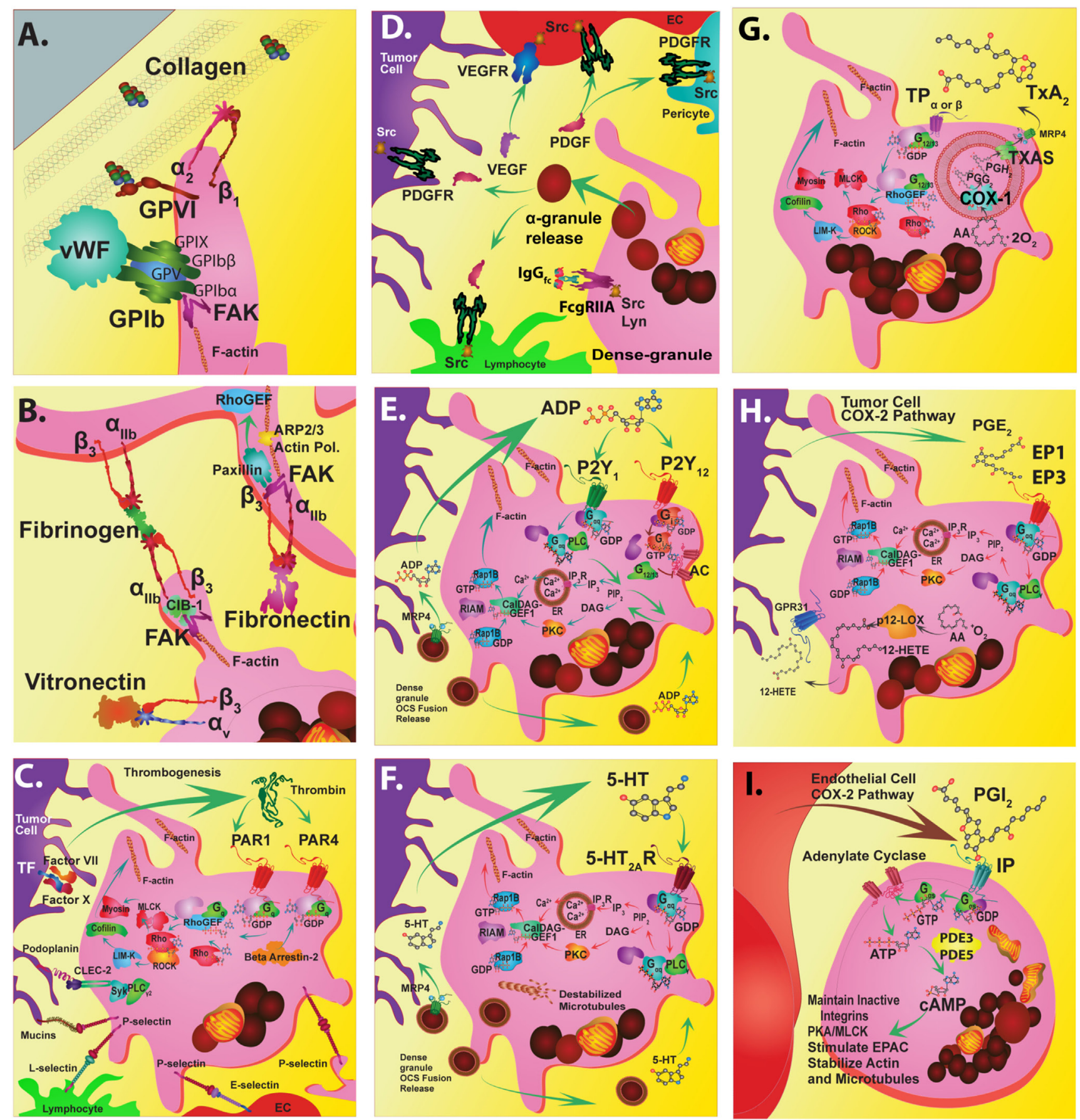


\begin{abstract}
FIGURE 1 | Platelet targeted therapeutics. The platelet plasma membrane displays multiple receptors that can interact with agonists, antagonists, matrix proteins, collagen, other platelets, endothelial cells, immune cells, and tumor cells. (A) Platelets adhere to the damaged vascular endothelium via GPIb-IX-V complex to von Willebrand factor (VWF) and via GPVI and GPla/lla $\left(\alpha_{2 \beta 1}\right)$ to collagen. (B) Focal adhesion kinase (FAK) helps mediate GPVI binding to collagen among other integrin-mediated interactions. FAK inhibitors could also potentially inhibit GPIlb/llla $\left(\alpha_{\| 1 \mid b \beta}\right)$ interactions that stimulate calcium and integrin-binding protein 1 (CIB-1) or paxillin that is linked to Rho guanine nucleotide exchange factor (Rho-GEF) signaling. Alternatively, FAK inhibition may also alter actin-related protein $2 / 3$ complex interactions during actin polymerization and shape change. Direct inhibition of GPIllb/lla interactions with fibrinogen or fibronectin during platelet aggregation can be disrupted by receptor antagonists. Similarly, direct inhibition of $a_{v} b_{3}$ interactions with vitronectin can also be inhibited. (C) Thrombin $G_{q}$ - $p$ rotein-coupled receptors involved in platelet activation are protease-activated receptors (PAR) 1 and 4. PARs are stimulated by tumor cell tissue factor-factor VII-factor X complex. Thrombin stimulation of PAR 1 acts through the Rho-GEF pathway while PAR4 $\mathrm{G}_{\mathrm{q}}$ activation occurs through beta arrestin-2. Signal transduction targets include Rhoassociated kinase (ROCK) or the cytoskeletal protein myosin II. Tumor cell podoplanin interacts with platelet C-type lectin domain family 2 (CLEC-2) that transduce signals through spleen tyrosine kinase (Syk) and phospholipase C gamma2 (PLC $\gamma_{2}$ ). Tumor cell mucins and other carbohydrate moieties interact with P-selectin are also targets. These P-selectin targets include interactions with lymphocyte L-selectins or endothelial cell E-selectins. (D) The release of alpha granules leads to localized increases in growth factors such as platelet-derived growth factors (PDGFs) and vascular endothelial cell growth factor (VEGF) and tyrosine kinase receptor stimulating molecules such as fc receptor stimulating molecules FcgammaRIla. (E) The activation of platelets by ADP (adenosine diphosphate) released from dense granules mainly involves $\mathrm{P}_{2} \mathrm{Y}_{1}$ or $\mathrm{P}_{2} \mathrm{Y}_{12}$ receptors. $\mathrm{P} 2 \mathrm{Y}_{1}$ signals through $\mathrm{G}_{\mathrm{ag}}$-protein-coupled receptors that stimulate PLC $\gamma$ followed by phosphatidylinositol 4,5-bisphosphate $\left(\mathrm{PIP}_{2}\right)$ and inositol trisphosphate $3\left(\mathrm{IP}_{3}\right)$ that stimulates its receptor embedded in the endoplasmic reticulum (ER), which causes calcium ion release $\left(\mathrm{Ca}^{2+}\right)$. Alternately, diacylglycerol (DAG) interacts with protein kinase C (PKC). These interactions impinge upon DAG-regulated guanine nucleotide exchange factor I (CalDAG-GEFI)-Ras-related protein 1 (Rap1) releasing Rap1-GTP-interacting adaptor molecule (RIAM) leading to actin changes. (F) Serotonin (5-hydroxytryptamine) is also released from dense granules that act through 5-hydroxytryptamine receptors $\left(5 \mathrm{HT}_{2 \mathrm{~A}} \mathrm{R}\right)$ that activate the $\mathrm{G}_{\mathrm{aq}}$ pathway and $\mathrm{Ca}^{2+}$ release. (G) An important antiplatelet agent is aspirin that is well known to prevent cancer progression. Aspirin irreversibly acetylates cyclooxygenase 1 (COX-1) eliminating all prostaglandin (PG) synthesis. COX-1 enzymatically adds two oxygens to arachidonic acid to produce $\mathrm{PGG}_{2}$ and then $\mathrm{PGH}$, which is converted to various $\mathrm{PG}$ sy synthase enzymes. Key platelet PGs are the potent pro-aggregatory agent thromboxane (TX) $A_{2}$ synthesized by TXA $A_{2}$ synthase. (H) Also, PGE 2 synthesized by PGE ${ }_{2}$ synthase. $\mathrm{TXA}_{2}$ and $P G E_{2}$ cause different platelet responses by stimulating various isoforms of G-protein-coupled TP or EP receptors. TP signals through $\mathrm{G}_{12 / 13}$ and Rho-GEF followed by Rho-associated kinase (ROCK), LIM domain kinase (LIMK), and cofilin and subsequent interactions with actin. Additional interactions include those with myosin light chain kinase followed by myosin. Similarly, $\mathrm{EP}_{3}$ receptors stimulate the same signal transduction pathways as $\mathrm{G}_{\mathrm{aq}}$-calcium release linked receptors. (I) An important $\mathrm{G}_{\text {as }}$-protein-coupled receptor is the IP for prostacyclin ( $\mathrm{PGI}_{2}$ ) that prevents aggregation by stimulating cyclic adenosine monophosphate (cAMP) production by adenylate cyclase (AC) and is influenced by phosphodiesterase 3 or 5 activity. Another abundant eicosanoid produced from arachidonic acid by platelets is 12(S)-HETE [12(S)-hydroxyeicosatetraenoic acid] via the activity of the platelet-type lipoxygenase (p12-LOX). Recently, 12-(S)HETE is proposed to activate orphan receptor GPR31.
\end{abstract}

to reduce the release of platelet proteins and the number of CTCs, respectively. Though the impact of platelet inhibition on CTC did not correlate with the platelet inhibition, aspirin therapy was favorable in reducing the release of platelet-angiogenic proteins $(94,115)$. Another phase II trial with metastatic cancer patients reported that aspirin treatment significantly reduced CTC numbers in metastatic CRC but did not have significance in metastatic breast cancer (116).

Epidemiological evidence also suggests that aspirin (and other NSAIDs) alone or in combination is beneficial in chemo prevention. In one such study, molecular pathological analyses conducted on 964 CRC patients suggested that the PIK3CA mutation in CRC may be used as a biomarker in identifying patients that could potentially receive aspirin as adjuvant therapy (117). The study provided association between mutated PIK3CA and longer survival in patients who received aspirin after cancer diagnosis. This association was lost in patients with wild-type protein (117). In other secondary epidemiological analyses, evidence from cardiovascular disease prevention studies suggests that aspirin therapy reduces $\mathrm{CRC}$ incidence and even mortality after 10 years of use (118-121). Several reports from literature also support that aspirin (and other NSAIDs) has proven to be effective in experimental models of cancer as well as in patient studies related to colorectal, breast, and ovarian cancers $(94,110-112,115$, 121-129). However, aspirin gastrointestinal toxicity potentially limits its use as a chemopreventive. To balance the risk versus the benefit of administering chemopreventive interventions such as aspirin, the US Preventive Services Task Force has made recommendations based on clinical evidence (130). The recommendations are directed toward primary prevention of cardiovascular disease and CRC in adults aged 50-59 years of age, particularly those at high risk for disease with the exception of individuals who are at increased risk of bleeding $(130,131)$. The benefits of cancer prevention with NSAID use to directly or indirectly target platelets and their activation can offer better outcomes in patients who are at risk of developing cancer.

\section{PLATELETS AND IMMUNE MODULATION}

Among other functions, platelets contribute centrally to immune regulation. They interact with immune cells and participate in the innate and adaptive immune functions (132-136). Platelets initiate or modulate immune cell and wound sterilization responses along with vesicle-mediated transfer of surface proteins onto the immune cells in conjunction with stimulation $(137,138)$. Platelets also have high amounts of transforming growth factor- $\beta$ (TGF $\beta$ ), which is perceived as an immunosuppressive factor modulating $\mathrm{T}$ regulatory cell homeostasis $(139,140)$. Blocking TGF $\beta 1$ receptor was shown to be beneficial in preventing ovarian cancer progression by the platelet-derived TGF $\beta 1$ (141). Functional impairment of normal recognition and elimination pathways fosters development of a pro-tumorigenic microenvironment. Tumor immune surveillance and tumor cell-platelet cross talk may thwart immune cell recognition or recruitment of effector immune cells to tumors. The most intriguing reports show that platelets can directly suppress the immune cells that target or eliminate cancer cells. In one study, platelets inhibited and suppressed the function of CD8 as well as CD4 T cells mediated via TGF $\beta$ and lactate (55). In other studies, platelets were shown to protect tumor cells from natural killer (NK) cell cytotoxic activity by shielding them or by the transfer of MHC I onto the surface of tumor cells $(142,143)$. The importance of platelets becomes 
evident with respect to tumor immunity as platelets can not only modify immune cell responses and result in the silencing of the tumor targeted immunity but also modulate tumor cells by enveloping them or by conferring them a pseudonormal phenotype so they can go undetected under immune surveillance.

Among the many roles that platelets play in enriching the microenvironment for tumor cell survival, perhaps the most challenging to target may be the reversion of suppression on $\mathrm{CD}^{+} \mathrm{T}$ cells as platelets have been reported to inhibit CD8 $\mathrm{T}$ cell function (55). The $\mathrm{CD}^{+} \mathrm{T}$ cells have clinical relevance as their main function is to kill cancer cells and are predominant effectors in cancer immunotherapy (144). In CRC patients, the absence of activated $\mathrm{CD}^{+} \mathrm{T}$ cells within the tumor and tumor stroma predicted disease recurrence within 5 years, whereas for patients who do show presence of these $\mathrm{T}$ cells, predicts a long disease free survival (145). The predictive value of the $\mathrm{T}$ cell presence in the tumor has gained more importance in treatment response (146). If having platelets, especially those that have been educated by the tumor, within the tumor as well as in the microenvironment could potentially interfere with the $\mathrm{T}$ cell functioning, then targeting these tumor cell educated platelets could be a key consideration in managing cancer immunotherapy.

Another important factor in cancer immunotherapy is the expression of programmed death-ligand 1 (PD-L1) on the tumor cells. It is of significance as it interacts with and inhibits the cytotoxic $\mathrm{CD}^{+} \mathrm{T}$ cells by engaging with their surface programmed cell death 1 (PD-1) receptor $(147,148)$. PD-L1 therefore, is an indicative marker of immune suppression and is an important target in cancer immuno-oncology field. Recently, it was shown that PD-L1 expressed on non-tumor cells can also have an inhibitory effect on the cytotoxic $\mathrm{CD}^{+} \mathrm{T}$ cell responses against the tumor (149). Immune checkpoint inhibitors that inhibit the interaction of PD-L1 with immune cells has been widely used in clinical trials to relieve the immune cells of this tumor suppression (150-158). Therapy with this strategy alone using PD-L1 blocking antibodies showed a mixed response within the patient populations leading to the development of vaccines and T cell stimulatory molecules, or drug combinations along with PD-L1 inhibitors to improve the efficacy of immunotherapy by targeting more pathways that lead to tumor cell death and growth suppression (159-165). Several factors such as differential PD-L1 expression on tumors, negligible presence of tumor infiltrating lymphocytes, presence of other inhibiting marks on the immune cells, and other host factors could be contributing to the failure of response to anti-PD1/PD-L1 monotherapy. Moreover, the persistence of $\mathrm{PD}-\mathrm{L} 1$ expression or the $\mathrm{PD}-\mathrm{L} 1$ positive CTCs after anti-PD-L1 therapy in non-small cell lung cancer (NSCLC) patients correlated with progressive disease, suggestive of an escape mechanism to check point therapy (166). There could be some connection between unresponsive CTCs and platelet numbers in circulation as escape mechanisms for CTCs from immune surveillance could be achieved by being entrapped within platelet aggregates, or by expressing platelet proteins on their surface and masking themselves. Support for this notion comes from a study showing that patients who had higher platelet counts showed poorer response to PD-L1 therapy. The study showed that elevated platelet to lymphocyte ratio before treatment was associated with shorter overall survival and progression free survival in metastatic NSCLC patients who underwent nivolumab therapy (167). In light of these findings, the inhibition of platelets to boost or sustain immunotherapy responses is a highly viable option. Targeting platelets was shown to enhance adoptive T cell cancer therapy suggesting that platelet inhibition could lead to more durable immunotherapy responses. Genetically modified mice with dysfunctional platelets were used to model adoptive $\mathrm{T}$ cell therapy responses to demonstrate that platelets are restrictive to $\mathrm{T}$ cell mediated cancer immunotherapy and inhibiting platelet function could help improve immunotherapy response with active T cells (55).

\section{CONNECTING NSAIDs AND CHECKPOINT BLOCKADE}

Interesting observations recently showed a positive correlation between COX-2 and PD-L1 responses in cancer cells (128). The upregulation of PD-L1 expression in tumor-infiltrating myeloid cells was also shown to be driven by COX-2 pathway (168). One of the major upstream targets of PD-L1 expression is hence presumed to be COX-2. COX-2 inhibition can therefore be explored to enhance the effect of immunotherapy. In other studies, COX-2 inhibition was used as an immunotherapyenhancing tool. NSAID celecoxib, a COX-2 inhibitor, was shown to enhance the proliferation of NK T cells derived from laryngeal cancer patients (169). The inhibition of COX-2 was also shown to negatively impact immune evasion of tumor cells, as its inhibition was shown to synergize with PD-L1 blockade suggesting that COX inhibitors could be used in combination with immunotherapy (170). Other preclinical studies have also reported similarly that inhibiting cyclooxygenase pathway can have a synergistic effect with PD-L1 inhibitors (128). Aspirin and other NSAIDs that selectively target platelets, COX-2, or both could potentially be used as adjuvants with immunotherapy to impact the aberrant platelet driven or cyclooxygenase driven anti-immune tumor responses. Tumor heterogeneity and molecular subtypes, surface markers, microenvironment as well as chronic inflammation and other risk factors may sub-stratify patients for adjuvant treatment. In the case of CRC, these factors may segregate patients not only based on the type subtype but also by the kind of response they might show to therapy $(171,172)$. Microsatellite instability high status in CRC can also influence checkpoint blockade responses. For example, nivolumab provided durable responses and disease control in pretreated patients with dMMR/MSI-H metastatic CRC and could potentially be a new treatment option for these patients. Since inflammation is often associated with platelet activity these patients may also benefit from NSAID use (134). In order to understand which patient is most likely to benefit from a therapy or a combination of drugs, data from larger clinical trials and longer patient follow up is needed. Finally, aspirin or other NSAIDs recommendations to a patient will depend on their tumor consensus molecular profiling, platelet counts, along with their risks in developing adverse events. However, the available data from clinical trials suggests that the benefits of long-term aspirin use outweigh the risks in most cases. 


\section{CONCLUSION}

Platelets that primarily participate in normal wounding processes are also known to be involved in immune regulation, and tumor cell cross talk. Strong experimental and clinical evidence supports an active involvement of platelets in tumorigenesis and metastasis. Tumor-educated platelets have the potential to be used in cancer diagnostic and screening approaches. High platelet counts seem to correlate with poor treatment outcomes. The interference of platelets with immune cell functioning could be of importance in designing immunotherapy approaches with platelet inhibitors as adjuvants. The use of aspirin and other platelet-targeted drugs in inhibiting platelet function has been established in several clinical studies and can be readily administered to patients based on their

\section{REFERENCES}

1. Menter DG, Tucker SC, Kopetz S, Sood AK, Crissman JD, Honn KV. Platelets and cancer: a casual or causal relationship: revisited. Cancer Metastasis Rev (2014) 33(1):231-69. doi:10.1007/s10555-014-9498-0

2. Menter DG, Kopetz S, Hawk E, Sood AK, Loree JM, Gresele P, et al. Platelet "first responders" in wound response, cancer, and metastasis. Cancer Metastasis Rev (2017) 36(2):199-213. doi:10.1007/s10555-017-9682-0

3. SylmanJL, Mitrugno A, Tormoen GW, Wagner TH, MallickP,McCartyOJT. Platelet count as a predictor of metastasis and venous thromboembolism in patients with cancer. Converg Sci Phys Oncol (2017) 3(2):1-12. doi:10.1088/2057-1739/aa6c05

4. Sørensen HT, Mellemkjaer L, Steffensen FH, Olsen JH, Nielsen GL. The risk of a diagnosis of cancer after primary deep venous thrombosis or pulmonary embolism. N Engl J Med (1998) 338(17):1169-73. doi:10.1056/ NEJM199804233381701

5. Levitan N, Dowlati A, Remick SC, Tahsildar HI, Sivinski LD, Beyth $\mathrm{R}$, et al. Rates of initial and recurrent thromboembolic disease among patients with malignancy versus those without malignancy. Risk analysis using Medicare claims data. Medicine (Baltimore) (1999) 78(5):285-91. doi:10.1097/00005792-199909000-00001

6. Alexandrakis MG, Passam FH, Moschandrea IA, Christophoridou AV, Pappa CA, Coulocheri SA, et al. Levels of serum cytokines and acute phase proteins in patients with essential and cancer-related thrombocytosis. Am J Clin Oncol (2003) 26(2):135-40. doi:10.1097/00000421-200304000-00007

7. Seretis C, Youssef H, Chapman M. Hypercoagulation in colorectal cancer: what can platelet indices tell us? Platelets (2015) 26(2):114-8. doi:10.3109/ 09537104.2014.894969

8. Wan S, Lai Y, Myers RE, Li B, Hyslop T, London J, et al. Preoperative platelet count associates with survival and distant metastasis in surgically resected colorectal cancer patients. J Gastrointest Cancer (2013) 44(3):293-304. doi:10.1007/s12029-013-9491-9

9. Alder H, Taccioli C, Chen H, Jiang Y, Smalley KJ, Fadda P, et al. Dysregulation of miR-31 and miR-21 induced by zinc deficiency promotes esophageal cancer. Carcinogenesis (2012) 33(9):1736-44. doi:10.1093/carcin/bgs204

10. Karagöz B, Sücüllü İ, Sayan Ö, Bilgi O, Tuncel T, Filiz A, et al. Platelet indices in patients with colorectal cancer. Centr Eur J Med (2010) 5(3):365-8. doi:10.2478/s11536-009-0077-7

11. Watt DG, Proctor MJ, Park JH, Horgan PG, McMillan DC. The neutrophil-platelet score (NPS) predicts survival in primary operable colorectal cancer and a variety of common cancers. PLoS One (2015) 10(11):e0142159. doi:10.1371/journal.pone.0142159

12. Wlodarczyk M, Kasprzyk J, Sobolewska-Wlodarczyk A, Wlodarczyk J, Tchórzewski M, Dziki A, et al. Mean platelet volume as a possible biomarker of tumor progression in rectal cancer. Cancer Biomark (2016) 17(4):411-7. doi:10.3233/CBM-160657

13. Zhao JM, Wang YH, Yao N, Wei KK, Jiang L, Hanif S, et al. Poor prognosis significance of pretreatment thrombocytosis in patients with colorectal cancer: a meta-analysis. Asian Pac J Cancer Prev (2016) 17(9):4295-300.

14. Dymicka-Piekarska V, Matowicka-Karna J, Osada J, Kemona H, Butkiewicz AM. Changes in platelet CD 62P expression and soluble P-selectin disease state and platelet profile. Hence, targeting platelet-driven responses in enhancing the reactivation of cancer immunity appears to be a reasonable therapeutic strategy.

\section{AUTHOR CONTRIBUTIONS}

PKM, ML, AVS and DM wrote the manuscript. SK, MJO and DM edited and provided feedback on relevant sections to include in the manuscript.

\section{FUNDING}

Colorectal Cancer Moon Shot, Cancer Center Support Grant (P30 CA016672).

concentration in surgically treated colorectal carcinoma. Adv Med Sci (2006) 51:304-8.

15. Guillem-Llobat P, Dovizio M, Alberti S, Bruno A, Patrignani P. Platelets, cyclooxygenases, and colon cancer. Semin Oncol (2014) 41(3):385-96. doi:10.1053/j.seminoncol.2014.04.008

16. Gay LJ, Felding-Habermann B. Contribution of platelets to tumour metastasis. Nat Rev Cancer (2011) 11(2):123-34. doi:10.1038/nrc3004

17. Mantur M, Snarska J, Sidorska A, Ostrowska H, Kruszewska-Wnorowska K, Wojszel J. Changes in PDGF concentration in surgically treated colorectal carcinoma. Adv Med Sci (2008) 53(1):37-41. doi:10.2478/v10039-008-0030-z

18. Zhao L, Bi Y, Kou J, Shi J, Piao D. Phosphatidylserine exposing-platelets and microparticles promote procoagulant activity in colon cancer patients. J Exp Clin Cancer Res (2016) 35:54. doi:10.1186/s13046-016-0328-9

19. Dymicka-Piekarska V, Kemona H, Piotrowski Z, Gryko M, Milewski Z, Matowicka-Karna J. Does colorectal cancer influence platelet activation? Przegl Lek (2003) 60(11):716-8.

20. Cho MS, Bottsford-Miller J, Vasquez HG, Stone R, Zand B, Kroll MH, et al. Platelets increase the proliferation of ovarian cancer cells. Blood (2012) 120(24):4869-72. doi:10.1182/blood-2012-06-438598

21. Davis AN, Afshar-Kharghan V, Sood AK. Platelet effects on ovarian cancer. Semin Oncol (2014) 41(3):378-84. doi:10.1053/j.seminoncol.2014.04.004

22. Lin RJ, Afshar-Kharghan V, Schafer AI. Paraneoplastic thrombocytosis: the secrets of tumor self-promotion. Blood (2014) 124(2):184-7. doi:10.1182/ blood-2014-03-562538

23. Mnjoyan Z, Li J, Afshar-Kharghan V. Factor $\mathrm{H}$ binds to platelet integrin alphaIIbbeta3. Platelets (2008) 19(7):512-9. doi:10.1080/09537100802238494

24. Stone RL, Nick AM, McNeish IA, Balkwill F, Han HD, Bottsford-Miller J, et al. Paraneoplastic thrombocytosis in ovarian cancer. N Engl J Med (2012) 366(7):610-8. doi:10.1056/NEJMoa1110352

25. Wang R, Stone RL, Kaelber JT, Rochat RH, Nick AM, Vijayan KV, et al. Electron cryotomography reveals ultrastructure alterations in platelets from patients with ovarian cancer. Proc Natl Acad Sci U S A (2015) 112(46):1426671. doi:10.1073/pnas.1518628112

26. Hu Q, Wang M, Cho MS, Wang C, Nick AM, Thiagarajan P, et al. Lipid profile of platelets and platelet-derived microparticles in ovarian cancer. BBA Clin (2016) 6:76-81. doi:10.1016/j.bbacli.2016.06.003

27. Haemmerle M, Taylor ML, Gutschner T, Pradeep S, Cho MS, Sheng J, et al. Platelets reduce anoikis and promote metastasis by activating YAP1 signaling. Nat Commun (2017) 8(1):310. doi:10.1038/s41467-017-00411-z

28. Denslow A, Świtalska M, Jarosz J, Papiernik D, Porshneva K, Nowak M, et al. Clopidogrel in a combined therapy with anticancer drugs-effect on tumor growth, metastasis, and treatment toxicity: studies in animal models. PLoS One (2017) 12(12):e0188740. doi:10.1371/journal.pone.0188740

29. Hsueh C, Tao L, Zhang M, Cao W, Gong H, Zhou J, et al. The prognostic value of preoperative neutrophils, platelets, lymphocytes, monocytes and calculated ratios in patients with laryngeal squamous cell cancer. Oncotarget (2017) 8(36):60514-27. doi:10.18632/oncotarget.16234

30. O'Sullivan JM, Preston RJS, Robson T, O'Donnell JS. Emerging roles for von Willebrand factor in cancer cell biology. Semin Thromb Hemost (2017) 44(2):159-66. doi:10.1055/s-0037-1607352 
31. Tang M, Jiang L, Lin Y, Wu X, Wang K, He Q, et al. Platelet microparticle-mediated transfer of miR-939 to epithelial ovarian cancer cells promotes epithelial to mesenchymal transition. Oncotarget (2017) 8(57):97464-75. doi:10.18632/oncotarget.22136

32. Tjon-Kon-Fat LA, Lundholm M, Schröder M, Wurdinger T, ThellenbergKarlsson C, Widmark A, et al. Platelets harbor prostate cancer biomarkers and the ability to predict therapeutic response to abiraterone in castration resistant patients. Prostate (2018) 78(1):48-53. doi:10.1002/pros.23443

33. Ho-Tin-Noe B, Boulaftali Y, Camerer E. Platelets and vascular integrity: how platelets prevent bleeding in inflammation. Blood (2018) 131(3):277-88. doi:10.1182/blood-2017-06-742676

34. Honn KV, Tang DG, Chen YQ. Platelets and cancer metastasis: more than an epiphenomenon. Semin Thromb Hemost (1992) 18(4):392-415. doi:10.1055/ s-2007-1002578

35. Janowska-Wieczorek A, Wysoczynski M, Kijowski J, Marquez-Curtis L, Machalinski B, Ratajczak J, et al. Microvesicles derived from activated platelets induce metastasis and angiogenesis in lung cancer. Int J Cancer (2005) 113(5):752-60. doi:10.1002/ijc.20657

36. Jansen F, Yang X, Hoyer FF, Paul K, Heiermann N, Becher MU, et al. Endothelial microparticle uptake in target cells is annexin I/phosphatidylserine receptor dependent and prevents apoptosis. Arterioscler Thromb Vasc Biol (2012) 32(8):1925-35. doi:10.1161/ATVBAHA.112.253229

37. Zucker S, Pei D, Cao J, Lopez-Otin C. Membrane type-matrix metalloproteinases (MT-MMP). Curr Top Dev Biol (2003) 54:1-74. doi:10.1016/ S0070-2153(03)54004-2

38. Best MG, Sol N, In 't Veld SGJG, Vancura A, Muller M, Niemeijer AN, et al. Swarm intelligence-enhanced detection of non-small-cell lung cancer using tumor-educated platelets. Cancer Cell (2017) 32(2):238-52.e9. doi:10.1016/j. ccell.2017.07.004

39. Joosse SA, Pantel K. Tumor-educated platelets as liquid biopsy in cancer patients. Cancer Cell (2015) 28(5):552-4. doi:10.1016/j.ccell.2015.10.007

40. Best MG, Sol N, Kooi I, Tannous J, Westerman BA, Rustenburg F, et al. RNASeq of tumor-educated platelets enables blood-based pan-cancer, multiclass, and molecular pathway cancer diagnostics. Cancer Cell (2015) 28(5):666-76. doi:10.1016/j.ccell.2015.09.018

41. Zhu J, Strickler JH. Clinical applications of liquid biopsies in gastrointestinal oncology. J Gastrointest Oncol (2016) 7(5):675-86. doi:10.21037/ jgo.2016.08.08

42. Feller SM, Lewitzky M. Hunting for the ultimate liquid cancer biopsy - let the TEP dance begin. Cell Commun Signal (2016) 14(1):24. doi:10.1186/ s12964-016-0147-9

43. Hudzik B, Szkodzinski J, Gorol J, Niedziela J, Lekston A, Gasior M, et al. Platelet-to-lymphocyte ratio is a marker of poor prognosis in patients with diabetes mellitus and ST-elevation myocardial infarction. Biomark Med (2015) 9(3):199-207. doi:10.2217/bmm.14.100

44. Hudzik B, Szkodziński J, Lekston A, Gierlotka M, Poloński L, Gasior M. Mean platelet volume-to-lymphocyte ratio: a novel marker of poor short- and long-term prognosis in patients with diabetes mellitus and acute myocardial infarction. J Diabetes Complications (2016) 30(6):1097-102. doi:10.1016/j. jdiacomp.2016.04.010

45. Kurtul A, Acikgoz SK. Usefulness of mean platelet volume-to-lymphocyte ratio for predicting angiographic no-reflow and short-term prognosis after primary percutaneous coronary intervention in patients with ST-segment elevation myocardial infarction. Am J Cardiol (2017) 120(4):534-41. doi:10.1016/j.amjcard.2017.05.020

46. Chu SG, Becker RC, Berger PB, Bhatt DL, Eikelboom JW, Konkle B, et al. Mean platelet volume as a predictor of cardiovascular risk: a systematic review and meta-analysis. J Thromb Haemost (2010) 8(1):148-56. doi:10.1111/j.1538-7836.2009.03584.x

47. Greisenegger S, Endler G, Hsieh K, Tentschert S, Mannhalter C, Lalouschek W. Is elevated mean platelet volume associated with a worse outcome in patients with acute ischemic cerebrovascular events? Stroke (2004) 35(7):1688-91. doi:10.1161/01.STR.0000130512.81212.a2

48. Slavka G, Perkmann T, Haslacher H, Greisenegger S, Marsik C, Wagner OF, et al. Mean platelet volume may represent a predictive parameter for overall vascular mortality and ischemic heart disease. Arterioscler Thromb Vasc Biol (2011) 31(5):1215-8. doi:10.1161/ATVBAHA.110.221788

49. Kara A, Guven M, Yilmaz MS, Demir D, Elden H. Are neutrophil, platelet and eosinophil-to-lymphocyte ratio and red blood cell distribution width can be used for nasal polyposis? Eur Arch Otorhinolaryngol (2018) 275(2):409-13. doi:10.1007/s00405-017-4821-3

50. Li DY, Hao XY, Ma TM, Dai HX, Song YS. The prognostic value of platelet-to-lymphocyte ratio in urological cancers: a meta-analysis. Sci Rep (2017) 7(1):15387. doi:10.1038/s41598-017-15673-2

51. Suzuki G, Yamazaki H, Aibe N, Masui K, Sasaki N, Shimizu D, et al. Clinical usefulness of the platelet-to lymphocyte ratio in patients with angiosarcoma of the face and scalp. Int J Mol Sci (2017) 18(11):1-11. doi:10.3390/ ijms18112402

52. Takeuchi H, Abe M, Takumi Y, Hashimoto T, Kobayashi R, Osoegawa A, et al. The prognostic impact of the platelet distribution width-to-platelet count ratio in patients with breast cancer. PLoS One (2017) 12(12):e0189166. doi:10.1371/journal.pone.0189166

53. Wang L, Liang D, Xu X, Jin J, Li S, Tian G, et al. The prognostic value of neutrophil to lymphocyte and platelet to lymphocyte ratios for patients with lung cancer. Oncol Lett (2017) 14(6):6449-56. doi:10.3892/ol.2017. 7047

54. Wu S, Wan Q, Xu R, Zhu X, He H, Zhao X. Systematic review and meta-analysis of the prognostic value of preoperative platelet-to-lymphocyte ratio in patients with urothelial carcinoma. Oncotarget (2017) 8(53):91694-702. doi:10.18632/oncotarget.21162

55. Rachidi S, Metelli A, Riesenberg B, Wu BX, Nelson MH, Wallace C, et al. Platelets subvert $\mathrm{T}$ cell immunity against cancer via GARP-TGFbeta axis. Sci Immunol (2017) 2(11):1-12. doi:10.1126/sciimmunol.aai7911

56. Kanikarla-Marie P, Lam M, Menter DG, Kopetz S. Platelets, circulating tumor cells, and the circulome. Cancer Metastasis Rev (2017) 36(2):235-48. doi:10.1007/s10555-017-9681-1

57. Gray AJ, Reeves JT, Harrison NK, Winlove P, Laurent GJ. Growth factors for human fibroblasts in the solute remaining after clot formation. J Cell Sci (1990) 96(Pt 2):271-4.

58. Brown BG, Mahley R, Assmann G. Swine aortic smooth muscle in tissue culture. Some effects of purified swine lipoproteins on cell growth and morphology. Circ Res (1976) 39(3):415-24. doi:10.1161/01.RES.39.3.415

59. Ross R. Connective tissue cells, cell proliferation and synthesis of extracellular matrix-a review. Philos Trans R Soc Lond B Biol Sci (1975) 271(912):247-59. doi:10.1098/rstb.1975.0049

60. Vavken P, Saad FA, Fleming BC, Murray MM. VEGF receptor mRNA expression by ACL fibroblasts is associated with functional healing of the ACL. Knee Surg Sports Traumatol Arthrosc (2011) 19(10):1675-82. doi:10.1007/ s00167-011-1443-y

61. Borrelli V, di Marzo L, Sapienza P, Colasanti M, Moroni E, Cavallaro A. Role of platelet-derived growth factor and transforming growth factor betal the in the regulation of metalloproteinase expressions. Surgery (2006) 140(3):454-63. doi:10.1016/j.surg.2006.02.008

62. Tonelli P, Mannelli D, Brancato L, Cinotti S, Morfini M. Counting of platelet derived growth factor and transforming growth factor-beta in platelet-rich-plasma used in jaw bone regeneration. Minerva Stomatol (2005) 54(1-2):23-34.

63. Jain E, Sheth S, Dunn A, Zustiak SP, Sell SA. Sustained release of multicomponent platelet-rich plasma proteins from hydrolytically degradable PEG hydrogels. J Biomed Mater Res A (2017) 105(12):3304-14. doi:10.1002/ jbm.a.36187

64. Lei H, Xiao R, Tang XJ, Gui L. Evaluation of the efficacy of platelet-rich plasma in delivering BMSCs into 3D porous scaffolds. J Biomed Mater Res B Appl Biomater (2009) 91(2):679-91. doi:10.1002/jbm.b.31444

65. Mazzucco L, Balbo V, Cattana E, Borzini P. Platelet-rich plasma and platelet gel preparation using Plateltex. Vox Sang (2008) 94(3):202-8. doi:10.1111/j.1423-0410.2007.01027.x

66. Ishida K, Kuroda R, Miwa M, Tabata Y, Hokugo A, Kawamoto T, et al. The regenerative effects of platelet-rich plasma on meniscal cells in vitro and its in vivo application with biodegradable gelatin hydrogel. Tissue Eng (2007) 13(5):1103-12. doi:10.1089/ten.2006.0193

67. Kolostova K, Pinkas M, Jakabova A, Pospisilova E, Svobodova P, Spicka J, et al. Molecular characterization of circulating tumor cells in ovarian cancer. Am J Cancer Res (2016) 6(5):973-80.

68. Van Berckelaer C, Brouwers AJ, Peeters DJ, Tjalma W, Trinh XB, van Dam PA. Current and future role of circulating tumor cells in patients with epithelial ovarian cancer. Eur J Surg Oncol (2016) 42(12):1772-9. doi:10.1016/j. ejso.2016.05.010 
69. Blassl C, Kuhlmann JD, Webers A, Wimberger P, Fehm T, Neubauer H. Gene expression profiling of single circulating tumor cells in ovarian cancer establishment of a multi-marker gene panel. Mol Oncol (2016) 10(7):1030-42. doi:10.1016/j.molonc.2016.04.002

70. Cheung KJ, Ewald AJ. A collective route to metastasis: seeding by tumor cell clusters. Science (2016) 352(6282):167-9. doi:10.1126/science.aaf6546

71. Massague J, Obenauf AC. Metastatic colonization by circulating tumour cells. Nature (2016) 529(7586):298-306. doi:10.1038/nature17038

72. Menter DG, Steinert BW, Sloane BF, Gundlach N, O'Gara CY, Marnett LJ, et al. Role of platelet membrane in enhancement of tumor cell adhesion to endothelial cell extracellular matrix. Cancer Res (1987) 47(24 Pt 1):6751-62.

73. Crissman JD, Hatfield JS, Menter DG, Sloane B, Honn KV. Morphological study of the interaction of intravascular tumor cells with endothelial cells and subendothelial matrix. Cancer Res (1988) 48(14):4065-72.

74. Walsh TG, Metharom P, Berndt MC. The functional role of platelets in the regulation of angiogenesis. Platelets (2015) 26(3):199-211. doi:10.3109/095 37104.2014.909022

75. Kim KH, Barazia A, Cho J. Real-time imaging of heterotypic platelet-neutrophil interactions on the activated endothelium during vascular inflammation and thrombus formation in live mice.J Vis Exp (2013) (74). doi:10.3791/50329

76. Spectre G, Zhu L, Ersoy M, Hjemdahl P, Savion N, Varon D, et al. Platelets selectively enhance lymphocyte adhesion on subendothelial matrix under arterial flow conditions. Thromb Haemost (2012) 108(2):328-37. doi:10.1160/ TH12-02-0064

77. Breckenridge MT, Egelhoff TT, Baskaran H. A microfluidic imaging chamber for the direct observation of chemotactic transmigration. Biomed Microdevices (2010) 12(3):543-53. doi:10.1007/s10544-010-9411-8

78. Ellingsen T, Storgaard M, Møller BK, Buus A, Andersen PL, Obel N, et al. Migration of mononuclear cells in the modified Boyden chamber as evaluated by DNA quantification and flow cytometry. Scand J Immunol (2000) 52(3):257-63. doi:10.1046/j.1365-3083.2000.00766.x

79. Friedl $\mathrm{P}$, Wolf $\mathrm{K}$, Lammerding J. Nuclear mechanics during cell migration. Curr Opin Cell Biol (2011) 23(1):55-64. doi:10.1016/j.ceb.2010.10.015

80. Goubran HA, Stakiw J, Radosevic M, Burnouf T. Platelets effects on tumor growth. Semin Oncol (2014) 41(3):359-69. doi:10.1053/j. seminoncol.2014.04.006

81. Unwith S, Zhao H, Hennah L, Ma D. The potential role of HIF on tumour progression and dissemination. Int J Cancer (2015) 136(11):2491-503. doi:10.1002/ijc.28889

82. Schmidt EM, Kraemer BF, Borst O, Münzer P, Schönberger T, Schmidt C, et al. SGK1 sensitivity of platelet migration. Cell Physiol Biochem (2012) 30(1):259-68. doi:10.1159/000339062

83. Kraemer BF, Borst O, Gehring EM, Schoenberger T, Urban B, Ninci E, et al. PI3 kinase-dependent stimulation of platelet migration by stromal cell-derived factor 1 (SDF-1). J Mol Med (Berl) (2010) 88(12):1277-88. doi:10.1007/ s00109-010-0680-8

84. Brandt E, Ludwig A, Petersen F, Flad HD. Platelet-derived CXC chemokines: old players in new games. Immunol Rev (2000) 177:204-16. doi:10.1034/j.1600-065X.2000.17705.x

85. Meikle CK, Kelly CA, Garg P, Wuescher LM, Ali RA, Worth RG, et al. Cancer and thrombosis: the platelet perspective. Front Cell Dev Biol (2016) 4:147. doi:10.3389/fcell.2016.00147

86. Sharma D, Brummel-Ziedins KE, Bouchard BA, Holmes CE. Platelets in tumor progression: a host factor that offers multiple potential targets in the treatment of cancer. J Cell Physiol (2014) 229(8):1005-15. doi:10.1002/ jcp. 24539

87. Gil-Bernabe AM, Lucotti S, Muschel RJ. Coagulation and metastasis: what does the experimental literature tell us? Br J Haematol (2013) 162(4):433-41. doi:10.1111/bjh.12381

88. Grossi IM, Fitzgerald LA, Kendall A, Taylor JD, Sloane BF, Honn KV. Inhibition of human tumor cell induced platelet aggregation by antibodies to platelet glycoproteins Ib and IIb/IIIa. Proc Soc Exp Biol Med (1987) 186(3):378-83. doi:10.3181/00379727-186-3-RC1

89. Menter DG, Harkins C, Onoda J, Riorden W, Sloane BF, Taylor JD, et al. Inhibition of tumor cell induced platelet aggregation by prostacyclin and carbacyclin: an ultrastructural study. Invasion Metastasis (1987) 7(2):109-28.

90. Menter DG, Onoda JM, Moilanen D, Sloane BF, Taylor JD, Honn KV. Inhibition by prostacyclin of the tumor cell-induced platelet release reaction and platelet aggregation. J Natl Cancer Inst (1987) 78(5):961-9.
91. Menter DG, Onoda JM, Taylor JD, Honn KV. Effects of prostacyclin on tumor cell-induced platelet aggregation. Cancer Res (1984) 44(2):450-6.

92. Mezouar S, Darbousset R, Dignat-George F, Panicot-Dubois L, Dubois C. Inhibition of platelet activation prevents the P-selectin and integrin-dependent accumulation of cancer cell microparticles and reduces tumor growth and metastasis in vivo. Int J Cancer (2015) 136(2):462-75. doi:10.1002/ ijc. 28997

93. Rival Y, Del Maschio A, Rabiet MJ, Dejana E, Duperray A. Inhibition of platelet endothelial cell adhesion molecule-1 synthesis and leukocyte transmigration in endothelial cells by the combined action of TNF-alpha and IFN-gamma. J Immunol (1996) 157(3):1233-41.

94. Roop RP, Naughton MJ, Van Poznak C, Schneider JG, Lammers PE, Pluard TJ, et al. A randomized phase II trial investigating the effect of platelet function inhibition on circulating tumor cells in patients with metastatic breast cancer. Clin Breast Cancer (2013) 13(6):409-15. doi:10.1016/j.clbc.2013 08.006

95. Heldin $\mathrm{CH}$, Lennartsson J, Westermark B. Involvement of platelet-derived growth factor ligands and receptors in tumorigenesis. J Intern Med (2018) 283(1):16-44. doi:10.1111/joim.12690

96. Ehnman M, Ostman A. Therapeutic targeting of platelet-derived growth factor receptors in solid tumors. Expert Opin Investig Drugs (2014) 23(2):211-26 doi:10.1517/13543784.2014.847086

97. Jiang L, Luan Y, Miao X, Sun C, Li K, Huang Z, et al. Platelet releasate promotes breast cancer growth and angiogenesis via VEGF-integrin cooperative signalling. Br J Cancer (2017) 117(5):695-703. doi:10.1038/bjc.2017.214

98. Sobolewska B, Grimmel C, Gatsiou A, Sopova K, Klein J, Biedermann T, et al. Different effects of ranibizumab and bevacizumab on platelet activation profile. Ophthalmologica (2015) 234(4):195-210. doi:10.1159/000437057

99. Kononczuk J, Surazynski A, Czyzewska U, Prokop I, Tomczyk M, Palka J, et al. alphaIIbbeta3-integrin ligands: abciximab and eptifibatide as proapoptotic factors in MCF-7 human breast cancer cells. Curr Drug Targets (2015) 16(13):1429-37. doi:10.2174/1389450115666140804220441

100. Ramjiawan RR, Griffioen AW, Duda DG. Anti-angiogenesis for cancer revisited: Is there a role for combinations with immunotherapy? Angiogenesis (2017) 20(2):185-204. doi:10.1007/s10456-017-9552-y

101. Loren CP, Aslan JE, Rigg RA, Nowak MS, Healy LD, Gruber A, et al. The BCR-ABL inhibitor ponatinib inhibits platelet immunoreceptor tyrosine-based activation motif (ITAM) signaling, platelet activation and aggregate formation under shear. Thromb Res (2015) 135(1):155-60. doi:10.1016/j. thromres.2014.11.009

102. Nomura Y, Kaneko M, Miyata K, Yatomi Y, Yanagi Y. Bevacizumab and aflibercept activate platelets via FcgammaRIIa. Invest Ophthalmol Vis Sci (2015) 56(13):8075-82. doi:10.1167/iovs.15-17814

103. Thun MJ, Henley SJ, Patrono C. Nonsteroidal anti-inflammatory drugs as anticancer agents: mechanistic, pharmacologic, and clinical issues. JNatl Cancer Inst (2002) 94(4):252-66. doi:10.1093/jnci/94.4.252

104. Ruschitzka F, Borer JS, Krum H, Flammer AJ, Yeomans ND, Libby P, et al. Differential blood pressure effects of ibuprofen, naproxen, and celecoxib in patients with arthritis: the PRECISION-ABPM (prospective randomized evaluation of celecoxib integrated safety versus ibuprofen or naproxen ambulatory blood pressure measurement) Trial. Eur Heart J(2017) 38(44):3282-92. doi:10.1093/eurheartj/ehx508

105. Eccleston C, Cooper TE, Fisher E, Anderson B, Wilkinson NM. Nonsteroidal anti-inflammatory drugs (NSAIDs) for chronic non-cancer pain in children and adolescents. Cochrane Database Syst Rev (2017) 8:Cd012537. doi:10.1002/14651858.CD012537.pub2

106. Gunter BR, Butler KA, Wallace RL, Smith SM, Harirforoosh S. Non-steroidal anti-inflammatory drug-induced cardiovascular adverse events: a meta-analysis. J Clin Pharm Ther (2017) 42(1):27-38. doi:10.1111/jcpt.12484

107. Warner TD, Nylander S, Whatling C. Anti-platelet therapy: cyclo-oxygenase inhibition and the use of aspirin with particular regard to dual anti-platelet therapy. Br JClin Pharmacol (2011) 72(4):619-33. doi:10.1111/j.1365-2125.2011.03943.x

108. Sostres C, Gargallo CJ, Lanas A. Aspirin, cyclooxygenase inhibition and colorectal cancer. World J Gastrointest Pharmacol Ther (2014) 5(1):40-9. doi:10.4292/wjgpt.v5.i1.40

109. Su BB, Chen JH, Shi H, Chen QQ, Wan J. Aspirin may modify tumor microenvironment via antiplatelet effect. Med Hypotheses (2014) 83(2):148-50. doi:10.1016/j.mehy.2014.05.007 
110. Guillem-Llobat P, Dovizio M, Bruno A, Ricciotti E, Cufino V, Sacco A, et al. Aspirin prevents colorectal cancer metastasis in mice by splitting the crosstalk between platelets and tumor cells. Oncotarget (2016) 7(22):32462-77. doi:10.18632/oncotarget.8655

111. Mitrugno A, Sylman JL, Ngo AT, Pang J, Sears RC, Williams CD, et al. Aspirin therapy reduces the ability of platelets to promote colon and pancreatic cancer cell proliferation: implications for the oncoprotein c-MYC. Am J Physiol Cell Physiol (2017) 312(2):C176-89. doi:10.1152/ajpcell.00196.2016

112. Cooke NM, Spillane CD, Sheils O, O'Leary J, Kenny D. Aspirin and P2Y12 inhibition attenuate platelet-induced ovarian cancer cell invasion. BMC Cancer (2015) 15:627. doi:10.1186/s12885-015-1634-x

113. Alonso-Escolano D, Strongin AY, Chung AW, Deryugina EI, Radomski MW. Membrane type-1 matrix metalloproteinase stimulates tumour cell-induced platelet aggregation: role of receptor glycoproteins. Br J Pharmacol (2004) 141(2):241-52. doi:10.1038/sj.bjp.0705606

114. Dehmer SP, Maciosek MV, Flottemesch TJ. U.S. Preventive Services Task Force Evidence Syntheses, formerly Systematic Evidence Reviews, in Aspirin Use to Prevent Cardiovascular Disease and Colorectal Cancer: A Decision Analysis: Technical Report. Rockville, MD: Agency for Healthcare Research and Quality (US) (2015).

115. Holmes CE, Jasielec J, Levis JE, Skelly J, Muss HB. Initiation of aspirin therapy modulates angiogenic protein levels in women with breast cancer receiving tamoxifen therapy. Clin Transl Sci (2013) 6(5):386-90. doi:10.1111/cts.12070

116. Yang L, Lv Z, Xia W, Zhang W, Xin Y, Yuan H, et al. The effect of aspirin on circulating tumor cells in metastatic colorectal and breast cancer patients: a phase II trial study. Clin Transl Oncol (2017). doi:10.1007/s12094-017-1806-z

117. Liao X, Lochhead P, Nishihara R, Morikawa T, Kuchiba A, Yamauchi M, et al. Aspirin use, tumor PIK3CA mutation, and colorectal-cancer survival. N Engl J Med (2012) 367(17):1596-606. doi:10.1056/NEJMoa1207756

118. Chubak J, Kamineni A, Buist DSM, Anderson ML, Whitlock EP. U.S. Preventive Services Task Force Evidence Syntheses, formerly Systematic Evidence Reviews, in Aspirin Use for the Prevention of Colorectal Cancer: An Updated Systematic Evidence Review for the U.S. Preventive Services Task Force. Rockville, MD: Agency for Healthcare Research and Quality (US) (2015).

119. Chubak J, Whitlock EP, Williams SB, Kamineni A, Burda BU, Buist DS, et al. Aspirin for the prevention of cancer incidence and mortality: systematic evidence reviews for the U.S. Preventive Services Task Force. Ann Intern Med (2016) 164(12):814-25. doi:10.7326/M15-2117

120. Dehmer SP, Maciosek MV, Flottemesch TJ, LaFrance AB, Whitlock EP. Aspirin for the primary prevention of cardiovascular disease and colorectal cancer: a decision analysis for the U.S. Preventive Services Task Force. Ann Intern Med (2016) 164(12):777-86. doi:10.7326/M15-2129

121. Veettil SK, Lim KG, Ching SM, Saokaew S, Phisalprapa P, Chaiyakunapruk N. Effects of aspirin and non-aspirin nonsteroidal anti-inflammatory drugs on the incidence of recurrent colorectal adenomas: a systematic review with meta-analysis and trial sequential analysis of randomized clinical trials. $B M C$ Cancer (2017) 17(1):763. doi:10.1186/s12885-017-3757-8

122. Ciravolo V, Huber V, Ghedini GC, Venturelli E, Bianchi F, Campiglio M, et al. Potential role of HER2-overexpressing exosomes in countering trastuzumab-based therapy. J Cell Physiol (2012) 227(2):658-67. doi:10.1002/jcp.22773

123. Frouws MA, Rademaker E, Bastiaannet E, van Herk-Sukel MPP, Lemmens VE, Van de Velde CJH, et al. The difference in association between aspirin use and other thrombocyte aggregation inhibitors and survival in patients with colorectal cancer. Eur J Cancer (2017) 77:24-30. doi:10.1016/j. ejca.2017.02.025

124. Thon JN, Italiano JE. Platelet formation. Semin Hematol (2010) 47(3):220-6. doi:10.1053/j.seminhematol.2010.03.005

125. Zhang Y, Wei J, Liu S, Wang J, Han X, Qin H, et al. Inhibition of platelet function using liposomal nanoparticles blocks tumor metastasis. Theranostics (2017) 7(5):1062-71. doi:10.7150/thno.17908

126. Dachineni R, Kumar DR, Callegari E, Kesharwani SS, Sankaranarayanan R, Seefeldt T, et al. Salicylic acid metabolites and derivatives inhibit CDK activity: novel insights into aspirin's chemopreventive effects against colorectal cancer. Int J Oncol (2017) 51(6):1661-73. doi:10.3892/ijo.2017.4167

127. Garza-Trevino EN, Rodriguez-Gonzalez MS, Delgado Gonzalez P, AlonsoCruz YG, Alonso-Cruz YG, Soto-Dominguez A, et al. Remarkably higher efficacy and a wider safety window for nonfrontline over first-line drug combinations in the adenocarcinoma Colo 320DM cell line. J BUON (2017) 22(5):1115-21.
128. Botti G, Fratangelo F, Cerrone M, Liguori G, Cantile M, Anniciello AM, et al. COX-2 expression positively correlates with PD-L1 expression in human melanoma cells. J Transl Med (2017) 15(1):46. doi:10.1186/s12967-017-1150-7

129. Takiuchi T, Blake EA, Matsuo K, Sood AK, Brasky TM. Aspirin use and endometrial cancer risk and survival. Gynecol Oncol (2018) 148(1):222-32. doi:10.1016/j.ygyno.2017.10.026

130. Bibbins-Domingo K. Aspirin use for the primary prevention of cardiovascular disease and colorectal cancer: U.S. Preventive Services Task Force Recommendation Statement. Ann Intern Med (2016) 164(12):836-45. doi:10.7326/M16-0577

131. Richman IB, Owens DK. Aspirin for primary prevention. Med Clin North Am (2017) 101(4):713-24. doi:10.1016/j.mcna.2017.03.004

132. Ghasemzadeh M, Hosseini E. Platelet-leukocyte crosstalk: linking proinflammatory responses to procoagulant state. Thromb Res (2013) 131(3):191-7. doi:10.1016/j.thromres.2012.11.028

133. Li N. Platelet-lymphocyte cross-talk. J Leukoc Biol (2008) 83(5):1069-78. doi:10.1189/jlb.0907615

134. Semple JW, Italiano JE Jr, Freedman J. Platelets and the immune continuum. Nat Rev Immunol (2011) 11(4):264-74. doi:10.1038/nri2956

135. Weyrich AS, Zimmerman GA. Platelets: signaling cells in the immune continuum. Trends Immunol (2004) 25(9):489-95. doi:10.1016/j.it.2004.07.003

136. Ali RA, Wuescher LM, Worth RG. Platelets: essential components of the immune system. Curr Trends Immunol (2015) 16:65-78.

137. Sprague DL, Elzey BD, Crist SA, Waldschmidt TJ, Jensen RJ, Ratliff TL. Platelet-mediated modulation of adaptive immunity: unique delivery of CD154 signal by platelet-derived membrane vesicles. Blood (2008) 111(10):5028-36. doi:10.1182/blood-2007-06-097410

138. Laffont B, Corduan A, Rousseau M, Duchez AC, Lee CH, Boilard E, et al. Platelet microparticles reprogram macrophage gene expression and function. Thromb Haemost (2016) 115(2):311-23. doi:10.1160/TH15-05-0389

139. Li MO, Wan YY, Sanjabi S, Robertson AK, Flavell RA. Transforming growth factor-beta regulation of immune responses. Annu Rev Immunol (2006) 24:99-146. doi:10.1146/annurev.immunol.24.021605.090737

140. Assoian RK, Komoriya A, Meyers CA, Miller DM, Sporn MB. Transforming growth factor-beta in human platelets. Identification of a major storage site, purification, and characterization. J Biol Chem (1983) 258(11):7155-60.

141. Hu Q, Hisamatsu T, Haemmerle M, Cho MS, Pradeep S, Rupaimoole R, et al. Role of platelet-derived Tgfbetal in the progression of ovarian cancer. Clin Cancer Res (2017) 23(18):5611-21. doi:10.1158/1078-0432.CCR-16-3272

142. Placke T, Örgel M, Schaller M, Jung G, Rammensee HG, Kopp HG, et al. Platelet-derived MHC class I confers a pseudonormal phenotype to cancer cells that subverts the antitumor reactivity of natural killer immune cells. Cancer Res (2012) 72(2):440-8. doi:10.1158/0008-5472.CAN-11-1872

143. Nieswandt B, Hafner M, Echtenacher B, Männel DN. Lysis of tumor cells by natural killer cells in mice is impeded by platelets. Cancer Res (1999) 59(6):1295-300.

144. Jackson SR, Yuan J, Teague RM. Targeting CD8+ T-cell tolerance for cancer immunotherapy. Immunotherapy (2014) 6(7):833-52. doi:10.2217/imt.14.51

145. Mlecnik B, Tosolini M, Kirilovsky A, Berger A, Bindea G, Meatchi T, et al. Histopathologic-based prognostic factors of colorectal cancers are associated with the state of the local immune reaction. J Clin Oncol (2011) 29(6):610-8. doi:10.1200/JCO.2010.30.5425

146. Curtis NJ, Primrose JN, Thomas GJ, Mirnezami AH, Ottensmeier CH. The adaptive immune response to colorectal cancer: from the laboratory to clinical practice. Eur J Surg Oncol (2012) 38(10):889-96. doi:10.1016/j. ejso.2012.05.011

147. Pardoll DM. The blockade of immune checkpoints in cancer immunotherapy. Nat Rev Cancer (2012) 12(4):252-64. doi:10.1038/nrc3239

148. Chen DS, Mellman I. Oncology meets immunology: the cancer-immunity cycle. Immunity (2013) 39(1):1-10. doi:10.1016/j.immuni.2013.07.012

149. Kleinovink JW, Marijt KA, Schoonderwoerd MJA, van Hall T, Ossendorp F, Fransen MF. PD-L1 expression on malignant cells is no prerequisite for checkpoint therapy. Oncoimmunology (2017) 6(4):e1294299. doi:10.1080/2 162402X.2017.1294299

150. Barkdull S, Brownell I. PD-L1 blockade with avelumab: a new paradigm for treating Merkel cell carcinoma. Cancer Biol Ther (2017) 18(12):937-9. doi:10.1080/15384047.2017.1394552

151. Doi T, Piha-Paul SA, Jalal SI, Saraf S, Lunceford J, Koshiji M, et al. Safety and antitumor activity of the anti-programmed death-1 antibody pembrolizumab 
in patients with advanced esophageal carcinoma. JClin Oncol (2018) 36(1):61-7. doi:10.1200/JCO.2017.74.9846

152. Kaufman HL, Hunger M, Hennessy M, Schlichting M, Bharmal M, et al. Nonprogression with avelumab treatment associated with gains in quality of life in metastatic Merkel cell carcinoma. Future Oncol (2018) 14(3):255-66. doi:10.2217/fon-2017-0470

153. Li C, Zhang N, Zhou J, Ding C, Jin Y, Cui X, et al. Peptide blocking of PD-1/ PD-L1 interaction for cancer immunotherapy. Cancer Immunol Res (2018) 6(2):178-88. doi:10.1158/2326-6066.CIR-17-0035

154. Ling DC, Bakkenist CJ, Ferris RL, Clump DA. Role of immunotherapy in head and neck cancer. Semin Radiat Oncol (2018) 28(1):12-6. doi:10.1016/j. semradonc.2017.08.009

155. Norum J, Antonsen MA, Tollåli T, Al-Shibli K, Andersen G, Svanqvist KH, et al. Pembrolizumab as second-line therapy in non-small cell lung cancer in northern Norway: budget impact and expected gain-a model-based analysis. ESMO Open (2017) 2(3):e000222. doi:10.1136/esmoopen-2017-000222

156. Peters S, Kerr KM, Stahel R. PD-1 blockade in advanced NSCLC: a focus on pembrolizumab. Cancer Treat Rev (2017) 62:39-49. doi:10.1016/j. ctrv.2017.10.002

157. Reck M. Pembrolizumab as first-line therapy for metastatic non-smallcell lung cancer. Immunotherapy (2018) 10(2):93-105. doi:10.2217/ imt-2017-0121

158. Wang Y, Wu L, Tian C, Zhang Y. PD-1-PD-L1 immune-checkpoint blockade in malignant lymphomas. Ann Hematol (2018) 97(2):229-37. doi:10.1007/ s00277-017-3176-6

159. Hu Z, Ott PA, Wu CJ. Towards personalized, tumour-specific, therapeutic vaccines for cancer. Nat Rev Immunol (2018) 18(3):168-82. doi:10.1038/ nri.2017.131

160. Ferris RL, Lenz HJ, Trotta AM, García-Foncillas J, Schulten J, Audhuy F, et al. Rationale for combination of therapeutic antibodies targeting tumor cells and immune checkpoint receptors: harnessing innate and adaptive immunity through IgG1 isotype immune effector stimulation. Cancer Treat Rev (2017) 63:48-60. doi:10.1016/j.ctrv.2017.11.008

161. Hou Y, Nitta H, Wei L, Banks PM, Parwani AV, Li Z. Evaluation of immune reaction and PD-L1 expression using multiplex immunohistochemistry in HER2-positive breast cancer: the association with response to anti-HER2 neoadjuvant therapy. Clin Breast Cancer (2018) 18(2):e237-44. doi:10.1016/ j.clbc.2017.11.001

162. Li SD, Martial A, Schrock AB, Liu JJ. Extraordinary clinical benefit to sequential treatment with targeted therapy and immunotherapy of a BRAF V600E and PD-L1 positive metastatic lung adenocarcinoma. Exp Hematol Oncol (2017) 6:29. doi:10.1186/s40164-017-0089-y

163. Ray A, Das DS, Song Y, Hideshima T, Tai YT, Chauhan D, et al. Combination of a novel HDAC 6 inhibitor ACY-241 and anti-PD-L1 antibody enhances anti-tumor immunity and cytotoxicity in multiple myeloma. Leukemia (2018) 32(3):843-6. doi:10.1038/leu.2017.322
164. Zha H, Han X, Zhu Y, Yang F, Li Y, Li Q, et al. Blocking C5aR signaling promotes the anti-tumor efficacy of PD-1/PD-L1 blockade. Oncoimmunology (2017) 6(10):e1349587. doi:10.1080/2162402X.2017.1349587

165. Zhu X, Xu J, Cai H, Lang J. Carboplatin and programmed death-ligand 1 blockade synergistically produce a similar antitumor effect to carboplatin alone in murine ID8 ovarian cancer model. J Obstet Gynaecol Res (2018) 44(2):303-11. doi:10.1111/jog.13521

166. Nicolazzo C, Raimondi C, Mancini M, Caponnetto S, Gradilone A, Gandini $\mathrm{O}$, et al. Monitoring $\mathrm{PD}-\mathrm{L} 1$ positive circulating tumor cells in non-small cell lung cancer patients treated with the PD-1 inhibitor nivolumab. Sci Rep (2016) 6:31726. doi:10.1038/srep31726

167. Diem S, Schmid S, Krapf M, Flatz L, Born D, Jochum W, et al. Neutrophilto-lymphocyte ratio (NLR) and platelet-to-lymphocyte ratio (PLR) as prognostic markers in patients with non-small cell lung cancer (NSCLC) treated with nivolumab. Lung Cancer (2017) 111:176-81. doi:10.1016/j. lungcan.2017.07.024

168. Prima V, Kaliberova LN, Kaliberov S, Curiel DT, Kusmartsev S. COX2/ mPGES1/PGE2 pathway regulates PD-L1 expression in tumor-associated macrophages and myeloid-derived suppressor cells. Proc Natl Acad Sci U S A (2017) 114(5):1117-22. doi:10.1073/pnas.1612920114

169. Klatka J, Grywalska E, Hymos A, Guz M, Polberg K, Roliński J, et al. Cyclooxygenase-2 inhibition enhances proliferation of NKT cells derived from patients with laryngeal cancer. Anticancer Res (2017) 37(8): 4059-66. doi:10.21873/anticanres.11791

170. Zelenay S, van der Veen AG, Böttcher JP, Snelgrove KJ, Rogers N, Acton $\mathrm{SE}$, et al. Cyclooxygenase-dependent tumor growth through evasion of immunity. Cell (2015) 162(6):1257-70. doi:10.1016/j.cell.2015.08.015

171. Guinney J, Dienstmann R, Wang X, de Reyniès A, Schlicker A, Soneson C, et al. The consensus molecular subtypes of colorectal cancer. Nat Med (2015) 21(11):1350-6. doi:10.1038/nm.3967

172. Lam M, Roszik J, Kanikarla-Marie P, Davis JS, Morris J, Kopetz S, et al. The potential role of platelets in the consensus molecular subtypes of colorectal cancer. Cancer Metastasis Rev (2017) 36(2):273-88. doi:10.1007/ s10555-017-9678-9

Conflict of Interest Statement: The authors declare that the research was conducted in the absence of any commercial or financial relationships that could be construed as a potential conflict of interest.

Copyright (ㄷ) 2018 Kanikarla-Marie, Lam, Sorokin, Overman, Kopetz and Menter. This is an open-access article distributed under the terms of the Creative Commons Attribution License (CC BY). The use, distribution or reproduction in other forums is permitted, provided the original author(s) and the copyright owner are credited and that the original publication in this journal is cited, in accordance with accepted academic practice. No use, distribution or reproduction is permitted which does not comply with these terms. 